\title{
PENYELENGGARAAN MAKANAN, DAYA TERIMA MAKANAN, DAN TINGKAT ASUPAN SISWA ASRAMA KELAS UNGGULAN SMA 1 PEMALI BANGKA BELITUNG
}

\author{
(Food Service Management, Food Acceptance, and The Intake Level of Boarding School Students \\ Living in Dormitory SMA 1 Pemali Bangka Belitung)
}

Sutyawan ${ }^{1 *}$ dan Budi Setiawan ${ }^{1}$

'Departemen Gizi Masyarakat, Fakultas Ekologi Manusia, Institut Pertanian Bogor, 16680

\begin{abstract}
The objectives of this study were to assess food service management, food acceptance, and the consumption's level of students boarding school dormitory SMA 1 Pemali Bangka Belitung. The research was conducted in May-July 2013 with a cross sectional design. Subjects were purposively chosen with the total of 71 students. As many as $51.0 \%$ of components of food service management system have already been applied consisted of planning, purchasing, storage, processing, serving, personal hygiene, and sanitation. Spearman correlation analysis showed that the preference level for taste of food was significantly associated with energy and protein sufficiency level $(p<0.05)$. The preference level for temperature of food was significantly associated with sufficiency levels of phosphorus $(p<0.05)$. Preference level for temperature of food was significantly associated with compliance level of energy and iron $(p<0.05)$. The level of compliance was significantly associated with sufficiency level of energy, iron, phosphorus, and zinc $(p<0.05)$. Energy, protein, fosfor, iron intake from dormitory was significantly negatively associated with intake from non dormitory $(p<0.05)$.
\end{abstract}

Keywords: compliance level, food service management, preference level, sufficiency level

\begin{abstract}
ABSTRAK
Tujuan penelitian ini untuk mengetahui proses penyelenggaraan makanan, daya terima makanan, dan tingkat asupan siswa asrama kelas unggulan SMA 1 Pemali Bangka Belitung. Penelitian ini dilaksanakan pada bulan Mei hingga Juli 2013 dengan menggunakan desain cross-sectional. Subjek diambil secara purposive dengan total 71 siswa. Sebanyak $51.0 \%$ komponen sistem penyelenggaraan makanan sudah diterapkan yang terdiri dari perencanaan, pembelian, penyimpanan, pengolahan, penyajian, higiene perorangan, dan sanitasi. Uji korelasi Spearman menunjukkan bahwa tingkat kesukaan terhadap rasa makanan memiliki hubungan yang nyata dengan tingkat kecukupan energi dan protein $(p<0.05)$. Tingkat kesukaan terhadap suhu makanan berhubungan nyata dengan tingkat kecukupan fosfor $(p<0.05)$. Tingkat kesukaan terhadap suhu makanan memiliki hubungan yang nyata dengan tingkat kepatuhan energi dan zat besi $(p<0.05)$. Tingkat kepatuhan berhubungan nyata dengan tingkat kecukupan energi, besi, fosfor, and seng $(p<0.05)$. Asupan energi, protein, fosfor, dan besi dari dalam asrama berhubungan negatif nyata dengan asupan dari luar asrama $(p<0.05)$.
\end{abstract}

Kata kunci: penyelenggaraan makanan, tingkat kecukupan, tingkat kepatuhan, tingkat kesukaan

"Korespondensi: Departemen Gizi Masyarakat, Fakultas Ekologi Manusia (FEMA), Institut Pertanian Bogor, Bogor 16680. Email: sutyawan7@yahoo.com 


\section{PENDAHULUAN}

Masa remaja merupakan jembatan periode kehidupan anak dan dewasa yang berawal pada usia 9-10 tahun dan berakhir di usia 18 tahun. Pada periode ini terjadi pertumbuhan fisik dan proses pematangan fungsi-fungsi tubuh yang cepat sehingga asupan gizi pada remaja perlu diperhatikan (Almatsier 2011). Remaja merupakan kelompok yang rentan terhadap pengaruh lingkungan sehingga memengaruhi gaya hidup remaja termasuk kebiasaan mengonsumsi makanan. Masalah gizi pada remaja yang umum terjadi berkaitan dengan adanya pembatasan konsumsi makanan. Hal ini disebabkan karena keinginan untuk mengontrol berat badan secara berlebihan, ketidakpuasan dengan bentuk tubuh, timbulnya depresi ketika melihat orang yang gemuk dengan orang yang tidak gemuk (Crow et al. 2006).

Masalah gizi pada remaja lainnya berkaitan dengan pola makan kurang teratur yang disebabkan oleh banyaknya aktivitas terutama dari kegiatan di sekolah. Menurut Barners et al. (2007), masa remaja menghabiskan waktu di sekolah selama kurang lebih delapan jam dalam satu hari atau sepertiga dalam waktu sehari. Anak usia remaja (14-19 tahun) lebih banyak menghabiskan waktu untuk bersosialisasi dengan teman sebaya (Greca \& Harrison 2005). Remaja yang banyak menghabiskan untuk berkumpul dengan teman sebaya menyebabkan hubungan yang terbatas dan tertutup dengan orangtua dan keluarga (Jennifer \& Charlotte 2008). Menurut Fulkerson dan Sztainer (2006), waktu makan anak remaja lebih teratur jika makan bersama-sama dengan keluarga dan ada dorongan serta kepercayaan dari anggota keluarga.

Asupan gizi anak remaja perlu diperhatikan terutama mereka yang bersekolah dengan fasilitas asrama sehingga tidak tinggal bersama orangtua. Menurut Luo et al. (2009), asupan zat gizi pada siswa yang tinggal di asrama lebih rendah dibandingkan dengan siswa yang tidak tinggal di asrama. Beranjak dari hal tersebut, penting dilakukan pengkajian tentang tingkat konsumsi siswa yang tinggal di asrama serta sistem penyelenggaraan makanan yang menyediakan makanan bagi siswa.

Tujuan penelitian ini adalah mengkaji penyelenggaraan makanan, daya terima makanan, dan tingkat konsumsi siswa asrama kelas unggulan SMA 1 Pemali Bangka Belitung.

\section{METODE}

\section{Desain, Tempat, dan Waktu Penelitian}

Penelitian ini menggunakan desain cross-sectional dengan metode observasional, wawancara, dan pengisian kuesioner secara mandiri. Data mengenai penyelenggaraan makanan diperoleh melalui pengamatan langsung/observasional dengan bantu- an kuesioner dan wawancara kepada pengelola dan penjamah makanan. Sedangkan data daya terima makanan dan tingkat asupan siswa diperoleh dari pengisian kuesioner. Penelitian ini dilakukan dari bulan Mei hingga Juli 2013 di asrama kelas unggulan SMA Negeri 1 Kecamatan Pemali, Kabupaten Bangka, Provinsi Bangka Belitung. Asrama yang dijadikan tempat penelitian merupakan asrama campuran yang terdiri dari asrama putra dan putri. Pemilihan lokasi penelitian dilakukan secara purposive berdasarkan pertimbangan bahwa asrama kelas unggulan SMA Negeri 1 Pemali sudah mengadakan penyelenggaraan makanan bagi siswa yang wajib tinggal di asrama.

\section{Jumlah dan Cara Penarikan Subjek}

Subjek dalam penelitian ini adalah siswa kelas unggulan SMA Negeri 1 Pemali yang wajib tinggal di asrama. Penarikan jumlah subjek menggunakan rumus Slovin (Notoatmodjo 2005) dengan kriteria subjek adalah siswa kelas sepuluh dan sebelas yang tinggal di asrama, berbadan sehat atau tidak sedang sakit, bersedia mengikuti kegiatan penelitian sampai selesai ketika hari sekolah. Dari total populasi yang berjumlah 189 siswa, terpilih 71 siswa yang dapat digunakan dalam penelitian ini yang sudah memenuhi minimal subjek.

\section{Jenis dan Cara Pengumpulan Data}

Data yang digunakan adalah data primer dan data sekunder. Data primer diperoleh melalui pengamatan langsung, wawancara dengan bantuan kuesioner. Data primer meliputi karakteristik subjek, antropometri (tinggi badan dan berat badan), konsumsi pangan, sistem penyelenggaraan makanan, tingkat kesukaan dan tingkat kepatuhan konsumsi siswa terhadap menu yang disajikan oleh asrama kelas unggulan SMA 1 Pemali. Data sekunder meliputi data anggaran dasar untuk penyelenggaraan makanan, siklus menu, dan daftar makanan dalam satu siklus menu. Semua komponen data yang berkaitan dengan input dan proses penyelenggaraan makanan terdiri dari pertanyaan terbuka dengan dua pilihan jawaban yaitu sudah diterapkan atau belum diterapkan. Jika jawaban yang sudah diterapkan maka akan mendapat skor 1 dan jika jawaban yang belum diterapkan maka akan mendapat skor 0 . Komponen penyelenggaraan makanan berdasarkan sebaran besaran dikategorikan menjadi tiga yaitu kurang $(<60 \%)$, cukup $(60-79 \%)$, dan baik $(\geq 80 \%)$ (Pratomo 2012). Tingkat kepatuhan asupan sumber energi dan zat gizi siswa berdasarkan sebaran kepatuhan siswa dikategorikan menjadi dua yaitu kurang $(<90 \%)$ dan baik $(\geq 90 \%)$. Tingkat kesukaan siswa terhadap menu yang disajikan oleh pihak asrama diperoleh dari uji hedonik dikategorikan menjadi lima pilihan jawaban yaitu sangat tidak suka, tidak suka, biasa, suka, atau sangat suka. Ketersediaan energi dan zat gizi 
siswa diperoleh berupa data berat dan jenis pangan yang disediakan per hari serta dikonversikan dalam bentuk energi, protein, vitamin $C$, kalsium, seng, fosfor, dan zat besi dengan menggunakan Daftar Komposisi Bahan Makanan tahun 2010. Tingkat kecukupan energi dan zat gizi dihitung dengan cara membandingkan asupan energi dan zat gizi subjek dengan angka kecukupan gizi dalam sehari sesuai yang dianjurkan.

\section{Pengolahan dan Analisis Data}

Data yang terkumpul diolah dengan menggunakan program komputer Microsoft Excel 2007. Selain itu dilakukan analisis korelasi dengan menggunakan software SPSS versi 16.0 for Windows. Uji korelasi yang digunakan adalah Uji korelasi Spearman atau Pearson untuk mengetahui hubungan antara variabel. Uji beda yang dilakukan menggunakan uji beda independent sample T-test .

\section{HASIL DAN PEMBAHASAN}

\section{Penyelenggaraan Makanan di Asrama Kelas Unggul- an SMA 1 Pemali}

Penyelenggaraan makanan untuk makanan utama dilaksanakan dalam siklus menu tujuh hari pada waktu pagi, siang, dan malam (on-site food service). Pengadaan snack tambahan pada malam hari baru dilaksanakan pada awal bulan Mei 2013 dengan menggunakan jasa catering. Setiap hari penyelenggaraan makanan di asrama kelas unggulan SMA 1 Pemali menyediakan makanan untuk 197 orang dengan rincian sebanyak 63 siswa kelas $X$, siswa kelas XI sebanyak 62 orang, dan siswa kelas XII sebanyak 64 siswa, pengawas asrama sebanyak empat orang, serta penjaga keamanan asrama sebanyak tiga orang. Karyawan lainnya seperti pengelola makanan dan ibu yang membersihkan asrama tidak diprioritaskan untuk mendapatkan persediaan makanan dari asrama. Pengelola makanan dan ibu asrama dapat mengambil makanan jika terdapat sisa makanan dari yang disediakan.

\section{Input Penyelenggaraan Makanan}

Penyelenggaraan makanan di asrama kelas unggulan SMA 1 Pemali merupakan salah satu bentuk penyelenggaraan makan institusional (non-profit) dikarenakan tidak mencari keuntungan. Jum- lah tenaga kerja pengelola makanan adalah enam orang yang terdiri satu orang sebagai kepala dapur asrama serta lima orang lainnya sebagai anggota. Semua pekerja dapur berjenis kelamin perempuan dengan sebaran tingkat pendidikan terakhir SMA sebesar $67.0 \%$ dan SD sebesar $33.0 \%$. Sebaran umur pekerja dapur berada pada rentang 30-40 tahun sebesar $50.0 \%$, sisanya sebesar $50.0 \%$ berada pada rentang usia 40-50 tahun. Semua pekerja dapur tidak memiliki pekerjaan sampingan selain bekerja di dapur asrama. Anggaran dana untuk penyelenggaraan makanan di asrama kelas unggulan SMA 1 Pemali berasal dari bantuan program CSR PT Timah (Persero) Tbk. Besaran anggaran yang dipatok setiap harinya untuk tiga kali makan berjumlah Rp 2000 000. Anggaran tersebut digunakan untuk menyediakan makanan sebanyak 189 porsi yang terdiri dari kelas X dan XI. Terdapat beberapa ruangan di dalam dapur asrama yaitu gudang penyimpanan, ruang persiapan dan pengolahan yang digabung, kamar mandi, ruang penyajian, ruang makan, serta ruang pencucian. Ruang penerimaan bahan pangan belum tersedia di dapur asrama.

\section{Proses Penyelenggaraan Makanan}

Perencanaan menu. Penyelenggaraan makanan untuk makan utama di asrama kelas unggulan SMA 1 Pemali menerapkan siklus menu tujuh hari. Snack malam tidak memperhatikan siklus menu karena disediakan atas dasar keputusan pengawas asrama putri. Penyelenggaraan makanan asrama kelas unggulan SMA 1 Pemali telah menerapkan komponen tahap perencanaan menu sebesar $60.0 \%$, sedangkan sisanya sebesar $40.0 \%$ belum diterapkan. Proses perencanaan menu di asrama kelas unggulan SMA $1 \mathrm{Pe}$ mali dapat dilihat pada Tabel 1.

Pembelian bahan pangan. Jumlah bahan makanan yang akan dibeli ditentukan berdasarkan kebutuhan dari perencanaan menu. Pembelian bahan pangan dilakukan langsung oleh kepala dapur asrama. Jarak antara asrama dengan pasar induk terdekat yakni $10 \mathrm{~km}$, sehingga pembelian bahan pangan dapat dilakukan setiap hari. Bahan makanan diperoleh dari pembelian langsung ke pasar dan tempat lainnya (langganan). Bahan pangan tertentu seperti beras, gula pasir, bumbu, dan susu kotak dapat disimpan di ruang penyimpanan sehingga pembelian bahan pangan tersebut tidak dilakukan setiap

Tabel 1. Perencanaan Menu di Asrama Kelas Unggulan SMA 1 Pemali

\begin{tabular}{lcc}
\hline \multicolumn{1}{c}{ Perencanaan Menu } & \multicolumn{2}{c}{ Penilaian } \\
\cline { 2 - 3 } & Ya & Tidak \\
\hline Memperhatikan siklus menu & 1 & 0 \\
Menu disusun sesuai dengan biaya yang tersedia & 0 & 1 \\
Merencanakan menu memperhatikan bahan pangan yang digunakan & 1 & 0 \\
Menu yang direncanakan memperhatikan kebutuhan gizi penerima & 0 & 1 \\
Memperhatikan evaluasi menu & 1 & 0 \\
\hline
\end{tabular}


hari yakni sebanyak tiga kali sehari sesuai kebutuhan. Penyelenggaraan makanan asrama kelas unggulan SMA 1 Pemali telah menerapkan komponen tahap pembelian bahan pangan sebesar 33.3\% dan sisanya sebesar $67.7 \%$ belum diterapkan. Proses pembelian bahan pangan di asrama kelas unggulan SMA 1 Pemali dapat dilihat pada Tabel 2.

Penyimpanan bahan pangan. Penyelenggaraan makanan di asrama kelas unggulan SMA 1 Pemali sudah menerapkan komponen tahap penyimpanan bahan makanan sebesar $40.0 \%$ dan sisanya sebesar $60.0 \%$ belum diterapkan. Penyimpanan bahan pangan di asrama kelas unggulan SMA 1 Pemali dapat dilihat pada Tabel 2.

Pengolahan bahan pangan. Proses pengolahan di asrama kelas unggulan SMA 1 Pemali termasuk dalam kategori cukup yaitu sebesar $60.0 \%$ sudah diterapkan, sedangkan sisanya sebesar $40.0 \%$ belum diterapkan. Pengolahan bahan pangan di asrama kelas unggulan SMA 1 Pemali dapat dilihat pada Tabel 2 .

Penyajian makanan. Proses penyajian makanan dilakukan oleh ibu dapur dibantu siswa putri yang mendapat jatah piket makan. Proses distribusi pada penyelenggaraan makanan di asrama kelas unggulan SMA 1 Pemali disebut proses desentralisasi. Penyelenggaraan makanan di asrama kelas unggulan
SMA 1 Pemali sudah menerapkan proses penyajian makanan sebesar $50.0 \%$, sedangkan sisanya sebesar $50.0 \%$ belum diterapkan. Penyajian makanan di asrama kelas unggulan SMA 1 Pemali dapat dilihat pada Tabel 2.

Higiene dan sanitasi. Penilaian dilakukan berdasarkan komponen-komponen higiene perorangan dan sanitasi yang tercantum dalam Kepmenkes No. 715 tahun 2003. Setelah dilakukan penilaian, higiene perorangan pada penjamah makanan di asrama kelas unggulan SMA 1 Pemali termasuk kategori kurang yaitu 50.0\% sudah diterapkan dan sisanya $50.0 \%$ belum diterapkan. Sanitasi penyelenggaraan makanan di asrama kelas unggulan termasuk dalam kategori kurang. Sebanyak 53.0\% komponen sanitasi penyelenggaraan makanan sudah diterapkan. Berdasarkan hasil penelitian Mikkelsen dan Sondergard (2006) bahwa tantangan dalam menjaga sanitasi dan higiene agar selalu baik disebabkan oleh latar belakang para pekerja yang kurang, ditandai oleh pandangan dan sikap terhadap kebersihan dan sanitasi. Beberapa hal yang menjadi penyebab kurangnya inisiatif para pekerja dapur dalam menjaga kebersihan dan sanitasi antara lain cara pembersihan dan sanitasi yang membosankan, perencanaan manajemen peralatan dan prosedur yang kurang, serta pendidikan yang kurang.

Tabel 2. Pembelian, Penyimpanan, Pengolahan Bahan Pangan dan Penyajian Makanan di Asrama Kelas Unggulan SMA 1 Pemali

\begin{tabular}{|c|c|c|}
\hline \multirow{2}{*}{ Penyelenggaran Makanan } & \multicolumn{2}{|c|}{ Penilaian } \\
\hline & $\mathrm{Ya}$ & Tidak \\
\hline \multicolumn{3}{|l|}{ Pembelian Bahan Pangan: } \\
\hline Pembelian bahan pangan sudah sesuai dengan menu yang terdapat dalam siklus menu & 1 & 0 \\
\hline Mempertimbangkan kualitas dan kuantitas bahan pangan & 0 & 1 \\
\hline Bahan Pangan yang dibeli mempertimbangkan zat gizi & 0 & 1 \\
\hline \multicolumn{3}{|l|}{ Penyimpanan Bahan Pangan: } \\
\hline Menerapkan sistem First In First Out (FIFO) & 1 & 0 \\
\hline Penyimpanan bahan kering dan bahan basah sudah dipisahkan & 0 & 1 \\
\hline Suhu penyimpanan diperhatikan & 0 & 1 \\
\hline Jarak rak penyimpanan diperhatikan & 0 & 1 \\
\hline $\begin{array}{l}\text { Tempat penyimpanan bahan makanan harus terhindar dari kemungkinan kontaminasi baik oleh } \\
\text { bakteri, serangga, tikus, dan hewan lainnya }\end{array}$ & 1 & 0 \\
\hline \multicolumn{3}{|l|}{ Pengolahan Bahan Pangan: } \\
\hline Dilakukan tahap persiapan sebelum pengolahan bahan pangan & 1 & 0 \\
\hline Standarisasi resep, standarisasi bumbu, standarisasi prosedur pengolahan dan standarisasi waktu & 0 & 1 \\
\hline Standar porsi dalam proses pengolahan bahan pangan & 0 & 1 \\
\hline Diperhatikan penggunaan bahan tambahan pangan (penyedap rasa) & 1 & 0 \\
\hline Diperhatikan cara memotong dan pengolahan bahan pangan & 1 & 0 \\
\hline \multicolumn{3}{|l|}{ Penyajian Makanan: } \\
\hline Perhatikan jarak dan waktu tempuh dari tempat pengolahan makanan ke tempat penyajian & 1 & 0 \\
\hline Perhatikan wadah yang digunakan pada saat penyajian (alat hidang diberi tutup) & 0 & 1 \\
\hline Pelaksanaan penyajian makanan harus tepat waktu sesuai dengan yang telah ditentukan & 1 & 0 \\
\hline Memperhatikan penggunaan garnish dan menu yang disajikan diperhatikan dari segi warna & 0 & 1 \\
\hline
\end{tabular}




\section{Kategori Penyelenggaraan Makanan}

Penyelenggaraan makanan di asrama kelas unggulan SMA 1 Pemali termasuk dalam kategori kurang. Sebanyak $51.0 \%$ komponen penting dalam penyelenggaraan makanan baru diterapkan, sedangkan sisanya sebesar $49.0 \%$ belum diterapkan. Hal ini serupa dengan hasil penelitian Nurdianty (2012) tentang beberapa komponen penyelenggaraan makanan yang kurang di pusat pendidikan dan latihan pelajar dinas pendidikan pemuda dan olahraga Makassar. Komponen yang kurang meliputi input, yakni tidak terdapat ahli gizi dan supervisor. Kemudian dari segi proses, masih ada tiga prosedur kerja yang tidak dilaksanakan, yakni tidak adanya perhitungan kebutuhan gizi atlet secara individual, tidak adanya checklist penerimaan dan penimbangan bahan makanan, serta tidak terlaksananya suatu monitoring dan evaluasi. Kategori penerapan komponen penyelenggaraan makanan di asrama kelas unggulan SMA 1 Pemali dapat dilihat pada Tabel 3.

Tabel 3. Kategori Penerapan Komponen Penyelenggaraan Makanan di asrama Kelas Unggulan SMA 1 Pemali

\begin{tabular}{lcc}
\hline \multirow{2}{*}{$\begin{array}{c}\text { Kategori Penyelenggaraan } \\
\text { Makanan }\end{array}$} & \multicolumn{2}{c}{ Penilaian } \\
\cline { 2 - 3 } & $\begin{array}{c}\text { Sudah } \\
\text { Diterapkan }\end{array}$ & $\begin{array}{c}\text { Belum } \\
\text { Diterapkan }\end{array}$ \\
\hline Perencanaan menu & 3 & 2 \\
Pembelian bahan pangan & 1 & 2 \\
Penyimpanan bahan pangan & 2 & 3 \\
Pengolahan bahan pangan & 3 & 2 \\
Penyajian makanan & 2 & 2 \\
Higiene perorangan & 6 & 6 \\
Sanitasi & 9 & 8 \\
Total & 26 & 25 \\
\hline
\end{tabular}

\section{Output Penyelenggaraan Makanan}

Ketersediaan sumber energi dan zat gizi.

Ketersediaan energi dan zat gizi adalah output dari penyelenggaraan makanan. Berdasarkan hasil penelitian terlihat bahwa ketersediaan energi dan zat gizi per hari dari menu yang disediakan asrama belum beragam. Rata-rata ketersediaan energi dan protein per hari untuk satu siswa yaitu 1623 kkal dan 52.2 g. Rata-rata ketersediaan vitamin C, kalsium, fosfor, besi, dan seng berturut-turut yaitu $47.3 \mathrm{mg}, 237.4$ $\mathrm{mg}, 613.7 \mathrm{mg}, 10.9 \mathrm{mg}$, dan $4.4 \mathrm{mg}$. Ketersediaan fosfor dari menu makanan yang disediakan oleh asrama sudah dapat memenuhi kecukupan gizi siswa. Rata-rata ketersediaan protein dari menu makanan yang disediakan oleh asrama hanya dapat memenuhi kecukupan gizi siswa perempuan yang berumur 1619 tahun, sedangkan ketersediaan protein belum dapat memenuhi angka kecukupan protein untuk siswa laki-laki dan perempuan yang berumur 13-15 tahun. Ketersediaan energi, kalsium, besi, seng, dan vitamin $\mathrm{C}$ belum dapat memenuhi angka kecukupan gizi siswa. Kontribusi energi, protein, dan fosfor terhadap angka kecukupan gizi siswa sudah mencapai angka persentase lebih dari $60.0 \%$. Hal ini serupa dengan penelitian Kresic et al. (2007) di sebuah asrama siswa di Kroasia. Sebagian besar menu yang disediakan di asrama tersebut dapat menyediakan energi, protein, dan fosfor yang cukup untuk siswa.

Tingkat kesukaan. Penilaian terhadap makanan yang disediakan di asrama dilakukan dengan menggunakan uji kesukaan terhadap tiap menu yang disajikan dalam satu siklus menu selama tujuh hari yang terdiri dari penilaian warna, aroma, tekstur, kesesuaian porsi, rasa, dan suhu makanan. Menurut Gregoire \& Spears (2007), umumnya survei tingkat kesukaan menggunakan skala hedonik, dimana makanan yang dinilai oleh seseorang memiliki tingkatan, yaitu dari "sangat tidak suka" hingga "sangat suka". Tingkat kesukaan didefinisikan sebagai kesesuaian masing-masing karakteristik makanan (warna, aroma, tekstur, kesesuaian porsi, rasa, dan suhu makanan) terhadap selera konsumen. Sebagian besar siswa menilai pada tingkatan biasa untuk keseluruhan menu yang disediakan oleh asrama dari segi penilaian terhadap warna (72.8\%), aroma (68.8\%), tekstur $(71.0 \%)$, kesesuaian porsi $(70.8 \%)$, rasa $(61.0 \%)$, dan suhu makanan $(66.6 \%)$.

Penelitian Rogozenski dan Moskowitz (2006) menunjukkan bahwa terdapat dua faktor yang memengaruhi tingkat kesukaan terhadap siklus menu secara keseluruhan yaitu tingkat kesukaan hedonik untuk beberapa komponen makanan seperti cara penyajian, sayuran, salad, dan makanan penutup. dan suhu makanan ketika pertama disajikan.

Tingkat kepatuhan. Tingkat kepatuhan dapat dihubungkan dengan jenis makanan apa saja yang banyak atau sedikit dihabiskan siswa. Penentuan jenis makanan ini dilakukan secara kualitatif dengan menggunakan metode observasi partisipan. Berdasarkan pengamatan, lima jenis olahan makanan yang paling banyak dihabiskan siswa adalah nasi goreng, rendang sapi, ayam goreng tepung, ayam goreng, sate ayam. Sedangkan lima jenis olahan makanan yang paling banyak tidak dihabiskan siswa adalah sayur acar timun, tumis keladi, tumis kangkung toge, sayur asem, tumis daun singkong. Berdasarkan observasi yang dilakukan di tempat pencucian alat makan, jenis makanan berupa sayur mayur yang paling banyak bersisa di wadah makan siswa. Hal ini menunjukkan bahwa siswa cenderung tidak menghabiskan sayur-mayur dari menu yang telah disediakan. Berdasarkan hasil penelitian Giampaoli dan Khanna (2000), sayur-mayur merupakan jenis pangan yang paling banyak tidak dihabiskan pada penyelenggaraan makanan institusi. Sebagian besar siswa cenderung dapat menghabiskan olahan protein hewani yang berasal dari daging sapi dan ayam.

Rata-rata tingkat kepatuhan dengan kategori baik pada siswa laki-laki sebesar $61.5 \%$, sedangkan 
sisanya sebanyak 38.5\% memiliki tingkat kepatuhan yang kurang. Tingkat kepatuhan yang baik pada siswa perempuan lebih rendah dari siswa laki-laki dengan persentase sebanyak $39.2 \%$ dan sisanya sebanyak 60.8\% memiliki kepatuhan konsumsi yang kurang. Penelitian Anyika et al. (2009) menunjukkan bahwa makanan dari luar seperti snack berkontribusi cukup besar terhadap total asupan energi dan zat gizi sehari pada siswa perempuan. Kontribusi snack pada siswa yang bersekolah dengan fasilitas asrama secara signifikan lebih tinggi dibandingkan mahasiswa yang kuliah. Berdasarkan uji independent sample T-Test, tidak terdapat perbedaan yang nyata antara tingkat kepatuhan siswa laki-laki dan perempuan asrama kelas unggulan SMA 1 Pemali ( $p>0.05)$.

Asupan energi dan zat gizi. Rata-rata asupan energi dan zat gizi (protein, kalsium, besi, fosfor) siswa laki-laki lebih tinggi dibandingkan dengan siswa perempuan. Asupan vitamin C dan seng siswa perempuan lebih tinggi dibandingkan dengan siswa laki-laki. Secara umum, sikap makan ditentukan berdasarkan jenis kelamin antara anak laki-laki dan perempuan (Downs et al. 2007). Khususnya pada remaja putri dimana sikap makan dipengaruhi oleh perhatian mereka terhadap bentuk tubuh (Nowak 1998). Berdasarkan penelitian Maliye (2006), rata-rata asupan energi dan zat gizi (protein dan besi) pada remaja putri tergolong dalam kategori defisit.

Rata-rata kontribusi asupan energi dan zat gizi dari menu yang disediakan terhadap total asupan siswa perempuan (85.8\%) lebih besar dibandingkan siswa laki-laki (84.5\%). Lain halnya dengan makanan dari luar asrama, kontribusi terhadap total asupan pada siswa laki-laki lebih besar (15.6\%) dibandingkan dengan siswa perempuan (14.2\%). Hal ini menunjukkan bahwa siswa perempuan cenderung menghabiskan makanan yang disediakan oleh asrama dengan baik sehingga asupan yang berasal dari luar asrama sedikit berkurang. Berdasarkan hasil analisis uji beda independent sample T-test, tidak terdapat perbedaan yang nyata antara asupan dari dalam dan luar asrama antara siswa laki-laki dan siswa perempuan $(p>0.05)$.

Tingkat kecukupan energi dan zat gizi. Rata-rata tingkat kecukupan energi dan zat gizi (protein, fosfor, dan vitamin C) pada siswa perempuan sudah baik karena telah memenuhi persyaratan minimal cut off point. Rata-rata tingkat kecukupan fosfor pada siswa laki-laki termasuk dalam kategori baik. Rata-rata tingkat kecukupan besi dan kalsium pada siswa laki-laki dan perempuan termasuk dalam kategori kurang. Tingkat kecukupan energi, protein dan vitamin C pada siswa laki-laki termasuk dalam kategori kurang. Tingkat kecukupan energi dan zat gizi yang kurang pada siswa diduga karena penyelenggaraan makanan di asrama yang berada dalam kategori kurang. Menurut Luo et al. (2009), penye- lenggaraan makanan yang kurang baik di sebuah asrama dapat berpengaruh terhadap asupan zat gizi siswa yang tidak cukup. Berdasarkan hasil analisis uji beda independent sample T-test, terdapat perbedaan yang nyata antara tingkat kecukupan energi dan zat gizi (protein dan zat besi) antara siswa lakilaki dengan perempuan $(\mathrm{p}<0.05)$. Sedangkan tingkat kecukupan kalsium, fosfor, vitamin $C$, dan seng tidak memiliki perbedaan nyata antara siswa laki-laki dan perempuan $(p>0.05)$.

Sebagian besar siswa laki-laki memiliki tingkat kecukupan energi dengan kategori defisit ringan (47.2\%). Hal ini serupa dengan penelitian dari Salay dan Ferreira (1995) bahwa asupan energi tergolong kurang pada siswa yang disediakan makan siang oleh sekolah. Sebagian besar siswa perempuan memiliki tingkat kecukupan energi dalam kategori normal (60.0\%). Tingkat kecukupan protein sebagian besar siswa laki-laki (36.1\%) dan perempuan (42.9\%) termasuk dalam kategori normal. tingkat kecukupan kalsium sebagian besar siswa laki-laki (88.9\%) dan perempuan (94.3\%) termasuk dalam kategori kurang. Semua siswa (100.0\%) baik laki-laki dan perempuan memiliki tingkat kecukupan fosfor yang cukup. Tingkat kecukupan besi (61.1\%) dan seng $(83.3 \%)$ sebagian besar siswa laki-laki termasuk dalam kategori kurang. Tingkat kecukupan besi dan seng sebagian besar siswa perempuan termasuk dalam kategori kurang dengan persentase yang sama yaitu sebesar $82.9 \%$. Hal ini serupa dengan penelitian Asrina et al. (2013) bahwa asupan kalsium dan besi pada sebagian besar siswa di SMA 2 Tinggimoncong tergolong kurang dari menu yang disediakan oleh pihak penyelenggara makanan. Tingkat kecukupan vitamin C siswa laki-laki sebagian besar kurang (52.8\%), sedangkan siswa perempuan sebagian besar tergolong cukup (65.7\%).

Analisis Hubungan Tingkat Kesukaan dengan Tingkat Kecukupan dan Kepatuhan Energi dan Zat Gizi

Hasil analisis korelasi Spearman menunjukkan adanya hubungan antara tingkat kesukaan terhadap rasa makanan dengan tingkat kecukupan energi dan protein $(p<0.05)$. Hal ini menunjukkan bahwa semakin suka dengan rasa makanan maka semakin tinggi tingkat kecukupan energi protein dan sebaliknya. Berdasarkan hasil penelitian dari Woschnagg et al. (2002), kehilangan sensitivitas rasa dapat menyebabkan kehilangan berat badan. Sensitivitas rasa memiliki peran penting dalam mengontrol status gizi individu. Oleh karena itu, tingkat kesukaan terhadap rasa perlu diperhatikan untuk mengontrol asupan zat gizi serta status gizi.

Hasil analisis korelasi Spearman menunjukkan adanya hubungan antara tingkat kesukaan terhadap suhu makanan dengan tingkat kecukupan fosfor $(p<0.05)$. 
Hasil analisis korelasi Spearman menunjukkan adanya hubungan yang nyata antara tingkat kesukaan terhadap suhu makanan dengan tingkat kepatuhan energi dan besi $(p<0.05)$. Hal ini menunjukkan bahwa asupan energi dan besi akan semakin banyak dihabiskan jika suhu makanan disukai. Hasil penelitian Wright et al. (2006) menyebutkan bahwa suhu merupakan faktor terpenting dalam penyelenggaraan makanan untuk meningkatkan kepuasan konsumen. Suhu makanan perlu diperhatikan untuk meningkatkan rasa suka atau kepuasan konsumen agar asupan energi dan zat gizi juga meningkat.

\section{Analisis Hubungan Tingkat Kepatuhan dengan Tingkat Kecukupan Energi dan Zat Gizi}

Uji korelasi Spearman menunjukkan bahwa adanya hubungan yang nyata antara tingkat kepatuhan dengan tingkat kecukupan energi, besi, fosfor, dan seng $(p<0.05)$. Hal ini menunjukkan bahwa semakin banyak menghabiskan makanan sumber energi dan zat gizi (besi, fosfor, dan seng) maka tingkat kecukupan akan semakin baik. Tingkat kepatuhan berkaitan dengan kemampuan individu untuk menghabiskan makanan. Sisa makanan (food waste) yang banyak berkaitan erat dengan kurangnya asupan energi dan protein serta memiliki dampak pada malnutrisi yang berhubungan erat dengan penyakit komplikasi (Barton et al. 2000).

\section{Analisis Hubungan antara Asupan dari Dalam As- rama dan Luar Asrama}

Uji korelasi Pearson menunjukkan bahwa terdapat hubungan negatif yang nyata antara asupan energi $(p=0.000 ; r=-0.525)$ dan protein $(p=0.000 ; r=$ -0.514) dari dalam asrama dengan luar asrama. Berdasarkan uji korelasi Spearman, terdapat hubungan negatif yang nyata antara asupan fosfor $(p=0.000$; $r=-0.411)$ dan besi ( $p=0.020 ; r=-0.275)$ dari dalam asrama dengan makanan luar asrama. Artinya semakin tinggi asupan energi dan zat gizi dari dalam asrama maka semakin rendah asupan dari luar asrama dan sebaliknya. Hasil penelitian Anyika et al. (2009) yang membedakan asupan yang berasal dari jajanan snack antara siswa sekolah dengan mahasiswa menunjukkan kontribusi snack terhadap total asupan zat gizi pada siswa sekolah lebih besar dibandingkan mahasiswa. Oleh karena itu, kontribusi asupan yang berasal dari makanan yang disediakan di rumah pada siswa lebih kecil dibandingkan mahasiswa.

\section{KESIMPULAN}

Asrama kelas unggulan SMA 1 Pemali sudah menerapkan separuh komponen penting dalam sistem penyelenggaraan makanan. Rata-rata ketersediaan energi dan protein per hari untuk satu siswa dari menu yang disajikan oleh asrama yaitu
1623 kkal dan $52.2 \mathrm{~g}$. Rata-rata ketersediaan vitamin C, kalsium, fosfor, besi, dan seng berturut-turut yaitu $47.3 \mathrm{mg}, 237.4 \mathrm{mg}, 613.7 \mathrm{mg}, 10.9 \mathrm{mg}$ dan 4.4 mg. Sebagian besar siswa menilai pada tingkatan biasa untuk keseluruhan menu yang disediakan oleh asrama dari segi penilaian terhadap warna, aroma, tekstur, kesesuaian porsi, rasa, dan suhu makanan.

Rata-rata kontribusi asupan energi dan zat gizi dari menu asrama terhadap total asupan pada siswa perempuan lebih besar dibandingkan siswa laki-laki. Lain halnya dengan makanan dari luar asrama, kontribusi terhadap total asupan pada siswa laki-laki lebih besar dibandingkan dengan siswa perempuan. Rata-rata tingkat kecukupan energi dan zat gizi (protein, fosfor, dan vitamin C) pada siswa perempuan sudah baik. Tingkat kecukupan fosfor pada siswa laki-laki yang sudah dapat dikategorikan baik. Tingkat kecukupan besi dan kalsium pada siswa laki-laki dan perempuan termasuk dalam kategori kurang. Tingkat kecukupan energi, protein dan vitamin C pada siswa laki-laki termasuk dalam kategori kurang.

Hasil analisis korelasi Spearman menunjukkan adanya hubungan yang nyata tingkat kesukaan terhadap rasa makanan dengan tingkat kecukupan energi dan protein $(p<0.05)$. Selain itu, terdapat hubungan yang nyata antara tingkat kesukaan terhadap suhu makanan dengan tingkat kecukupan fosfor $(p<0.05)$. Adanya hubungan yang nyata tingkat kesukaan terhadap suhu makanan dengan tingkat kepatuhan energi dan besi $(p<0.05)$. Berdasarkan uji korelasi Spearman menunjukkan bahwa adanya hubungan yang nyata antara tingkat kepatuhan dengan tingkat kecukupan energi, besi, fosfor, dan seng $(p<0.05)$.

Uji korelasi Pearson menunjukkan bahwa terdapat hubungan negatif yang nyata antara asupan energi dan protein dari dalam asrama dengan luar asrama $(p<0.05)$. Berdasarkan uji korelasi Spearman, terdapat hubungan negatif yang nyata antara asupan fosfor dan besi dari dalam asrama dengan makanan luar asrama $(p<0.05)$. Sebaiknya diberikan pendidikan penyelenggaraan makanan kepada pengelola makanan serta penerapannya. Selain itu, perlu dilakukan evaluasi menu yang rutin untuk mengetahui jenis makanan apa yang tidak disukai oleh siswa sehingga dapat melaksanakan variasi menu. Pendidikan gizi tentang pentingnya konsumsi buah-buahan dan sayur-sayuran perlu diberikan kepada siswa.

\section{DAFTAR PUSTAKA}

Almatsier S et al. 2011. Gizi Seimbang dalam Daur Kehidupan. Gramedia Pustaka Utama, Jakarta.

Anyika JU, Uwaegbute AC, Olojede AO, \& Nwamatah JU. 2009. Nutrient intakes of adolescent girls 
in secondary schools and universities in Abia State of Nigeria. Pakistan Journal of Nutrition, 8(10), 1596-1602.

Asrina, Teti, Puspitasari A, Tonapa CL, Dachlan DM, \& Yustini. 2013. Pengetahuan, asupan, status gizi siswa dan manajemen penyelenggaraan makanan di SMA Negeri 2 Tinggimoncong Kabupaten Gowa Provinsi Sulawesi Selatan. Media Gizi Masyarakat Indonesia, 2(2), 90-97.

Barners GM, Hoffman JH, Weltw JW, Farrel MP, \& Dintcheff BR. 2007. Adolescents' time use: effects on substance use, delinquency, and sexual activity. Journal of Youth and Adolescence, 36, 697-710.

Barton AD, Beigg CL, Macdonald IA, \& Allison SP. 2000. High food wastage and low nutritional intakes in hospital patients. Journal of Clinical Nutrition, 19(6), 445-9.

Crow S, Eisenberg ME, Story M, \& Neumark-Sztainer D. 2006. Psychosocial and behavioral correlates of dieting among overweight and non-overweight adolescents. Journal Adolesc Health, 38, 569-574.

Downs D, Dinallo JM, Savage JS, \& Davison KK. 2007. Determinants of eating attitudes among overweight and nonoverweight adolescents. Journal Adolesc Health, 41,138-145.

Fulkerson JA \& Sztainer DN. 2006. Adolescent and parent views of family meals. J. Am. Diet. Assoc, 106, 526-532.doi: 10.1016/j. jada.2006.01.006

Giampaoli J \& Khanna S. 2000. The use of plate waste to determine resident food preferences in a long term care facility. Foodservice Research International, 12,51-57. doi: 10.1111/ j.1745-4506.2000.tb00004.

Gregoire MB \& Spears MC. 2007. Foodservice Organizations: A Managerial and Systems Approach 6th ed. Pearson Education, New Jersey.

Greca A \& Harrison H. 2005. Adolescent peer relations, friendships, and romantic relationships: do they predict social anxiety and depression?. J. Clin. Child Adolesc, 34 (1), 49-61.

Jennifer L\& Charlotte J. 2008. Peer relations among adolescents with female same-sex parents. American Psychological Association, 44(1), 117-126. doi:0.1037/0012-1649.44.1.117.

Kresic G, Simundic B, Mandic ML, Kendel G, \& Zezelj SP. 2008. Daily menus can result in suboptimal nutrient intakes, especially calcium, of adolescents living in dormitories. Journal of
Foodservice, 28(3),156-165. doi: 10.1016/j. nutres.2007.12.010.

Luo R, Shi Y, Zhang L, Liu C, Rozelle S, \& Sharbono B. 2009. Malnutrition in China's rural boarding schools: the case of primary schools in Shaanxi Province. APJE, 29(4), 481-501.

Maliye CH, Deshmukh PR, Gupts SS, Ksur S, Mehendele AM, \& Garg BS. 2006. Nutrient intake amongst rural adolescent girls of Wardha. Indian Journal Pediatrics, 73(2),139-141.

Mikkelsen BE \& Sondergard KG. 2006. Street-level bureaucrats and the implementation of cleaning and sanitation practices in foodservice: case findings from a study in Danish hospitals and nursing homes. Journal of Foodservice, 17 , 49-59. doi: $10.1111 / \mathrm{j} .1745-450$ .2006 .00020 .

Notoatmodjo S. 2005. Metodologi Penelitian Kesehatan. Rineka Cipta, Jakarta.

Nowak M. 1998. The weight-conscious adolescent: body image, food intake, and weight-related behavior. Journal Adolesc Health, 23, 389398.

Nurdianty, Radhiyah, Daetilan DM, \& Nawir N. 2012. Penyelenggaraan makanan dan tingkat kepuasan atlet di pusat pendidikan dan latihan pelajar dinas pendidikan pemuda dan olahraga Makassar. Media Gizi Masyarakat Indonesia, 1(2), 91-96.

Pratomo SW. 2012. Penyelenggaraan dan kontribusinya terhadap tingkat kecukupan energi dan zat gizi siswa pondok pesantren Al-Falak di Kota Bogor. [skripsi]. Departemen Gizi Masyarakat FEMA IPB, Bogor.

Rogozenski J \& Moskowitz H. 2006. A system for the preference evaluation of cyclic menus. Foodservice Research International, 2, 139-161. doi: 10.1111/j.1745-4506.1983.tb00270.

Salay E \& Ferreira DCJ. 1995. The nutritional value of nursery school meals served in campinas city, Brazil. Foodservice Research International, 8, 175-186. doi: 10.1111/j.1745-4506.1995. tb00086.

Woschnagg H, Stollberger C, \& Finsterer J. 2002. Loss of taste is loss of weight. Lancet, 359(9 321), 891-900.doi:10.1016/S0140-6736(02)07933

Wright OR, Connelly L.B, \& Capra S. 2006. Consumer evaluation of hospital foodservice quality: an empirical investigation. International Journal of Health Care Quality Assurance Incorporating Leadership in Health Services, 19(2-3), 181-194. 